\title{
Duke/UNC to helm the JCl in March 2012
}

A s the JCI went to press, ASCI members were returning their ballots to confirm Howard Rockman of Duke University as the next Editor in Chief of the JCI. Rockman will serve as Editor from March 2012 through February 2017 together with an Editorial Board based at Duke, the University of North Carolina, and Duke-NUS Graduate Medical School Singapore. Rockman has studied molecular mechanisms of cardiac hypertrophy and heart failure, concentrating on the regulation of $\mathrm{G}$ protein-coupled receptors and their downstream signaling pathways. The JCI recently sat down with Rockman to discuss his visions for the journal.

JCI: Why do you think Duke and UNC are the right place to house the JCI?

Rockman: The scientists at Duke and UNC are really outstanding. I've spent a lot of time speaking with the proposed Editors, and they're ready for it. They're energetic, they're committed, and they're excellent scientists.

JCI: Who are some of the people you have assembled to help you in this endeavor?

Rockman: In addition to a strong team of Deputy and Associate Editors, I have asked Bob Lefkowitz to chair a newly created Executive Council. This council will be responsible for evaluating our progress year to year, and providing editorial advice on papers that need additional review - like when an author feels like they haven't had a fair review. He'll also be in charge of working with us to determine if there's been any scientific malfeasance or breaches of scientific integrity.

The other senior member of the board will be David Virshup, from Duke-NUS Singapore. He's going to be our Asia Editor - we'll be looking to him to help us attract the best science in Asia that we might not already be getting.

The Deputy Editors will be Tom Coffman and Paul Noble of Duke and Norman Sharpless from UNC. They are outstanding scientists and I'm going to lean on them heavily for their advice and scientific knowledge, and of course for their sense of humor.

JCI: You cannot undervalue the need for comic relief in this job.

Rockman: Humor is a wonderful form of creativity, and Dr. Noble in particular is very good at getting us to laugh. You know, when you're this busy and working this hard, humor is really important.
JCI: What sort of papers do you want to encourage people to send in?

Rockman: What we want are papers that use basic science critical thinking, cellular systems, and tractable genetic models to identify new biological mechanisms that can be translated to better understand or treat a disease. It is also the Journal of Clinical Investigation, and I'd like to see more studies in humans. The paper I'd like to see is one where there are human studies, but the authors went back into a cellular or other model systems to understand the mechanism.

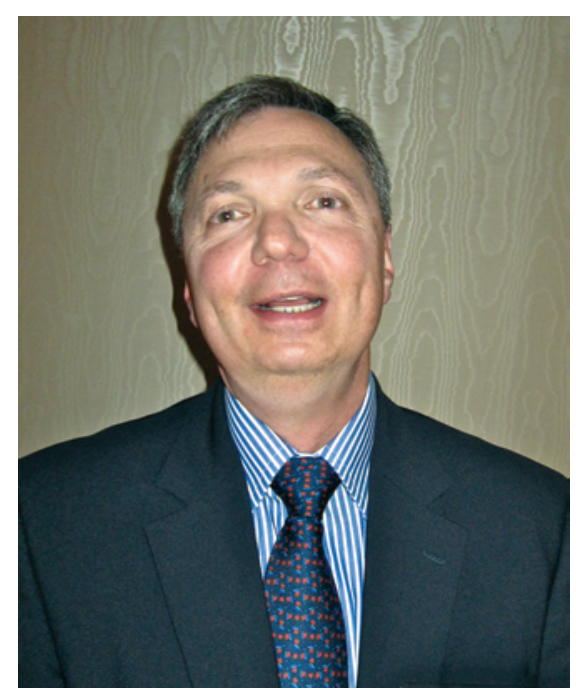

JCI: The JCI has recently joined 2011, and we have both a Facebook page and a Twitter feed. Do you think you're going to be actively tweeting as JCI Editor?

Rockman: I'm going to have to learn how to do that! During the application process, my son Michael went onto the JCI Facebook page and asked if he should join. Apparently he was number 99.

The way I like to get my information is so different from the way the younger generation does. I was recently sitting at the table after dinner reading the New York Times - I love the print; I love the smell of the paper and getting the ink on my fingers. Michael sat down at the table after dinner and was looking at his iPhone, and I looked up and in a somewhat scornful way and said, "Instead of playing games on your phone, why don't you pick up the paper?" And he turned the phone to me and he was reading David Brooks. And he said, "Dad, I'm reading today's news. You're reading yesterday's news.” Everyone gets their information in different ways. His generation wants to interact with media, not simply be passive, and I think we have to be responsive to a diverse constituency. Today people get their information in many ways. They don't just pick up a journal and thumb through it. The way for us to really get our message across and have our scientific discoveries read is to use all the available technology to enhance the experience.

JCI: What sort of things do you envision changing or adding to the front half of the JCI and online?

Rockman: Together with embracing new media, I want to look for different ways to tell the story of science. I would like to have podcasts linked to some articles, wherein we could interview senior authors and allow them to tell the story of their paper. It could almost be like you were sitting in a seminar and listening to them.

I'd also like to bring back into the JCI the legends in science: I have the idea to add a "Conversation with Giants" section wherein a new ASCI member could interview a legend in the field and get a sense of what it was like for them to be in science - their thrill of discovery.

The other article type I'd like to add is one where we explore a translational link between a paper that we publish and how it affects our health. These articles could explore how the basic science could affect our health and how we treat patients of a certain disease.

JCI: Any parting words about the intellectual stewardship of the JCI?

Rockman: I believe the JCI editorship is not a trophy, but a responsibility. Moreover, this is not my JCI, but our JCI. I think the journal should publish the best in biomedical science by generating new knowledge that advances our understanding of the biology of disease and leads to therapeutic advances. After reading a JCI paper, I want our readers to sit back and say "Wow, what an amazing discovery - what a beautiful story."

\section{Ushma S. Neill}

